\title{
HEDONIC ANALYSIS OF PRICE IN THE ISTANBUL HOUSING MARKET
}

\author{
Berna KESKIN \\ Department of Town and Regional Planning, University of Sheffield, Western Bank, \\ Sheffield, S10 2TN, United Kingdom \\ E-mail:trp05bk@shef.ac.uk
}

Received 9 January 2008; accepted 27 March 2008

\begin{abstract}
The purpose of this paper is to explore the factors that affect housing prices in Istanbul. A hedonic price model is employed in order to examine housing price determinants with respect to property characteristics, socio-economic characteristics, neighbourhood quality characteristics, and locational factors. The results reveal that housing prices are affected by these factors: living area size, being in a low storey building, being in a secured site (with swimming pool and garage), and age of the building. In addition to these determinants, the length of time the inhabitants have lived in Istanbul, the average income of the household, neighbour satisfaction and earthquake risk of the area have effects on the residential prices in Istanbul. Further research is suggested by constructing a second model that includes neighbourhood dummy variables as a proxy for submarkets, and a multi-level modelling framework will be employed in order to analyse the urban housing submarket system.
\end{abstract}

KEYWORDS: Residential property market; Housing prices; Hedonic price models; Istanbul

\section{INTRODUCTION}

There is a vast literature that explores the structure and operation of urban housing systems. This literature tends to focus on the North American, Western European and South East Asian markets. There have been few studies of Turkish markets, as the relative immaturity of the housing research community, and the absence of suitable data has prohibited this sort of research. This situation has begun to change. In recent years, researchers have produced hedonic studies of the Istanbul housing system (Onder et al., 2004, Ozus et al., 2007). These papers have produced valuable insights to the determination of house prices. The analysis, however, has tended to provide only preliminary explorations of spatial market segmentation.

The purpose of this paper is to explore the factors that affect housing prices in Istanbul. In this study, housing price determinants are examined by employing a hedonic pricing model according to the neighbourhood administrative boundaries which can reflect the heterogeneous physical and socio-economical configuration.

The paper is organised in four further sections. The next section sets out the conceptual rationale for the study. This discussion highlights the limitations of standard hedonic models and, in particular, emphasises the problems with the treatment of spatial influences on markets structure. Section three provides 
some information on the study area and on the data used. Section four summarises the model results. Finally, the concluding part of the paper sets out the key findings and presents a programme for further research.

\section{CONCEPTUAL FRAMEWORK OF THE STUDY}

The fact, like in most urban areas, is that residential lands cover the largest proportion of the urban areas. The determinants of the housing prices can vary through out the interior structure of the housing unit and building, the structure of the neighbourhood that the house is located, market conditions and housing policies. The exterior determinants of housing prices are the component of physical, economic, social, cultural elements and accessibility to CBD, job locations and urban facilities.

According to the neoclassical approach the location of the housing unit, accessibility to CBD and travel time are the main facts that determine house prices or rental values. The foundations of the neoclassical economic approach are supported by hedonic price models that help to understand the housing preferences of the consumers. Thus hedonic models are taken into consideration, along with the physical structure of the housing unit, and spatial, demographical, and economic structure of neighbourhoods.

Explaining the determinants of the housing prices with only these factors is not enough to analyze the local housing system. Although the hedonic models are useful tools for understanding the housing segmentation, some conceptual constraints exist, such as the approach faults that capture the institutional factors. The hedonic models are useful tools not only for investigation of housing price changes, but also to operationalise the urban housing market system, but this is limited as a first stage of this study.
"Rather than perceiving a housing unit as providing homogeneous "housing services" at a single price, as in the access-space model, the hedonic literature postulates that house prices are determined by the value of each the individual physical and spatial characteristics of the housing unit" (Watkins, 2001, p. 2236). In addition to the characteristics of the residential unit, the spatial attributes determine the housing prices. The model's accuracy of predicted market values can be significantly improved by incorporating the spatial relationships in hedonic equations, and this can also reduce estimation errors for submarkets (Basu and Thibodeau, 1998; Bourassa et al., 2007). This can be achieved by three approaches, the first one being the inclusion of the distance or neighbourhood quality variable into the model (So et al., 1997; Watkins, 1998). The second approach is to employ a neighbourhood dummy variable as a proxy for submarkets like in (Rothenberg et al., 1991; Gallimore et al., 1996; Ozus et al., 2007). Finally, the third method is based on estimating a separate equation for each submarket. The identification of the submarkets can be done by grouping the administrative boundaries, definition of experts or classification by statistical methods such as cluster analysis (Adair et al., 1996; Bourassa et al., 1999; Watkins, 2001). In this study, neighbourhood quality variable is included into the model with the respect to spatial factors.

\section{STUDY AREA AND DATA}

\subsection{The study area}

Istanbul is Turkey's cultural, financial, educational, industrial and information centre, and is located on two continents: Europe and Asia. The advantage of this strategic location in the regions of Eastern Europe, Middle East and Soviet Republics attacks the attention of national and international investors. Istanbul has a population of 10 million (15\% of the to- 
tal population of Turkey) (Turkstat, 2007), and this surpasses the population of 22 EU countries (Eurostat, 2007).

The population grew from 1 million in 1950 to 5 million in 1980 , and 10 million in 2000. Between 1950 and 2000 the population increased tenfold (Turkstat, 2007). This dramatic increase in the demographic profile of the city indicates that Istanbul's urban growth process is not a balanced development. Like most of the large cities in developing countries, Istanbul's rapid population increase is because of the migration due to job opportunities and the variety in the facilities make Istanbul a destination point for migrants from other cities in Turkey.

The rapid growth of the city since the 1950s, due to rural migration, has affected the quality of life in various sections of the city. While some of the modern districts have become more attractive, the historic districts have lost high income population due to the deterioration of their neighbourhoods and settlement of low income migrants (Onder et. al., 2004). Because of this expansion of industrial areas and migration from rural areas, legitimating the dwelling type in Istanbul has developed from detached to multi-storey housing blocks since 1960. Multifamily Housing/Apartments are still the most common form of residential development in Istanbul.

On the other hand, when migrants first arrived in Istanbul during the 50's, they settled in peripheral areas of the city by constructing "gecekondu" literally meaning "illegal squat". The squatter settlements spread over a 51,760 ha area making $54 \%$ of the area of Istanbul illegal (Gokmen et al., 2006). Unlike the singlefamily "gecekondus" with garden which were built between the 50's and the 80's, today's "gecekondus" are unfinished multi-storey buildings constructed with cheap materials without plastering or flashing. Public authorities contributed to the chaotic development of the city and to the emergence of the legal-illegal divi- sion by legalizing the "gecekondu" settlements because of the popular politic concerns and vote apprehension (Keyder, 2005).

Like most cities in developing countries with the dynamics of growth and globalization, physical transformation has occurred since the mid 1980's in Istanbul. The construction of shopping malls, five-star hotels, new office areas, gated communities, the gentrification of the historical and deprived neighbourhoods and the expansion of the city, have transformed the city from mono-centric form to a polycentric structure. These global influences of neo-liberalism have resulted in the inequality among the socio-economic classes and the differences in the quality of the built environment.

All these changes have created locational advantages and disadvantages, which are reflected in demand for housing and housing prices. According to the 2000 Population Census, in Turkey, $68 \%$ of households are owners, whereas $24 \%$ are tenants. In Istanbul, $58 \%$ of the households are privately owned, whereas $35 \%$ are tenants (Turkstat, 2007). The reason that the rate of the ownership in Istanbul is less than Turkey's average is because of the high housing prices in Istanbul.

The total number of households is 2,550,607 and the average household size is $3,85 \mathrm{~m}^{2}$ which is below the Turkey average. According to the Property Registry office, there were 132,440 housing and land transactions in Istanbul in 2004, and in 2006 this increased to 188,478. The housing market of Istanbul has seen a very dynamic period since 2004 with significant new housing construction progress. New housing projects have reached between 50,000 and 70,000 dwelling units in the period of 2004-2007, of which $60 \%$ are located in the European continent [Based on information from an interview with Serdar Serdaroglu (MSc Urban Planner, Real Estate Manager)]. The increase in the number of new residential projects reflects the influence of both demand 
and supply. The raise in the number of residential developments indicates that property is one of the major investment tools. In addition to the increase in the number of residential developments, an increase in long-term housing loans coincides with declining inflation and the new mortgage law ratified by the Turkish Parliament in 2007 makes property an important investment vehicle in Istanbul.

In the last few years, the property market has enjoyed high appreciation in values in the Istanbul housing market. This has occurred along with urban growth, and especially the changing economic structure and a new regulatory system in housing finance.

\subsection{The data}

The database employed in this study was generated using two data sets. The first dataset is gathered from two major real estate agent's websites and this data set contains 2,175 transactions of single-family homes sold in Istanbul in November 2006 and in April. This dataset compiles observations from 348 submarkets constructed from 946 neighbourhoods in 32 districts. The second dataset is derived from a survey that was undertaken by
Istanbul Greater Municipality and provides information about the socio-economic structure of the neighbourhoods and the satisfaction of inhabitants of the city. [Deleting observations with missing values reduces the sample size to 1,517$]$.

Table 1 presents the descriptive statistics for the transactions data provided from two major real estate agencies, Remax and Turyap in Turkey. This data set provides the property characteristics of the hedonic model. The database comprises information on key variables such as, location, price, age, floor area, construction type, number of storeys of the building and the housing unit, elevators, garage, garden, balcony, security unit and swimming pool.

The average transaction price for the 2,175 properties is $\$ 251,082$, ranging from $\$ 34,000$ to $\$ 8,000,000$ (Figure 1). The average property area has $170 \mathrm{~m}^{2}$ of living space with 3.2 rooms and was 12 years old at the time of the sale.

Approximately half of the transactions $(52.2 \%)$ on the sale range from 0 to 8 years old, and this correlates with the Marmara Earthquake in 1999. Although there are buildings up to 150 years old in the range, the percentage of the $61-150$ year old building age group is $1.1 \%$ (Figure 2). The earthquake and also the in-

Table 1. Descriptive statistics of housing units for Istanbul transaction data N: 2175

\begin{tabular}{lllll}
\hline & Minimum & Maximum & Mean & Std. Deviation \\
\hline Price & 34013.60 & $8,000,000$ & $251,082.92$ & $382,467.37$ \\
Age & 0 & 150 & 12.22 & 14.578 \\
Area & 45 & 1920 & 170.08 & 123.063 \\
Room & 1 & 15 & 3.21 & 1.258 \\
Total storey & 1 & 27 & 5.96 & 3.060 \\
Flat & 0 & 1 & 0.90 & 0.302 \\
Detached & 0 & 1 & 0.10 & 0.300 \\
Elevator & 0 & 1 & 0.64 & 0.482 \\
Garden & 0 & 1 & 0.79 & 0.410 \\
Balcony & 0 & 1 & 0.92 & 0.277 \\
Garage & 0 & 1 & 0.78 & 0.412 \\
Security & 0 & 1 & 0.46 & 0.498 \\
Swimming pool & 0 & 1 & 0.19 & 0.394 \\
\hline
\end{tabular}


crease in housing prices together with the trend of investing in the property market caused rapid construction process in the last years.

The living space ranges from $45 \mathrm{~m}^{2}$ to $1920 \mathrm{~m}^{2}$ whereas the number of the rooms ranges from 1 to 15 (Figure 3). The number of rooms in the housing unit vary from 1 to 15 and the avarage number of rooms is 3 (Fig-

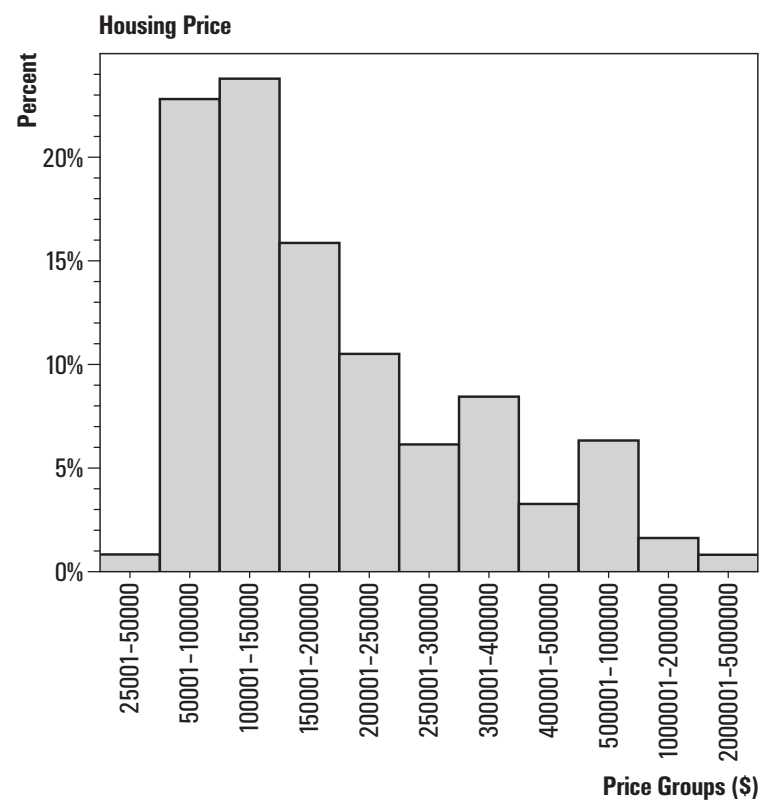

Figure 1. Sale prices for houses

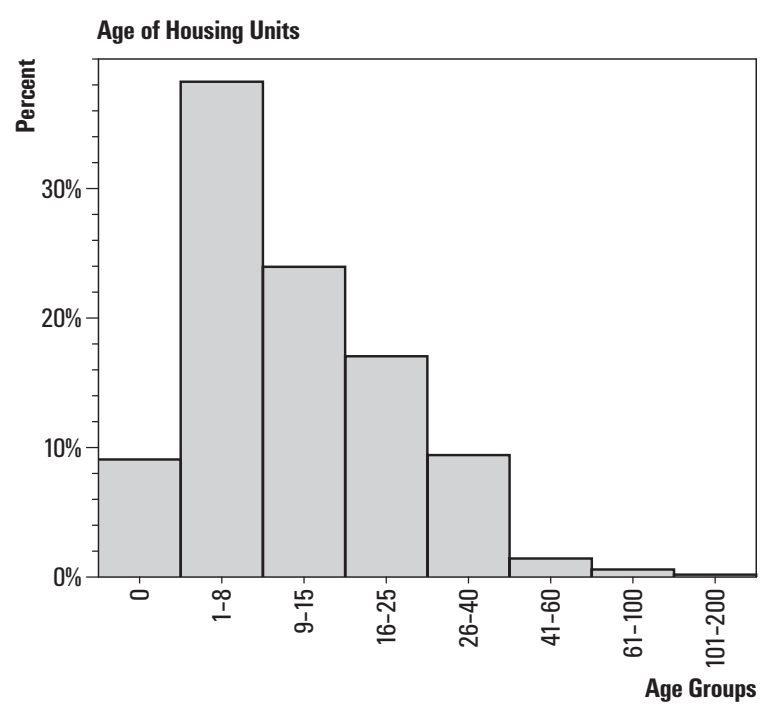

Figure 2. Age of the housing units ure 4). The average number of storeys of the buildings where the housing units exist is 6 (Figure 5) and $64 \%$ of the buildings has elevators. $90 \%$ of the housing units are flat (Figure 6) whereas $92 \%$ has a balcony, $78 \%$ has a garage and $79 \%$ has a garden. $46 \%$ of properties have a security system and $19 \%$ of them have swimming-pool.

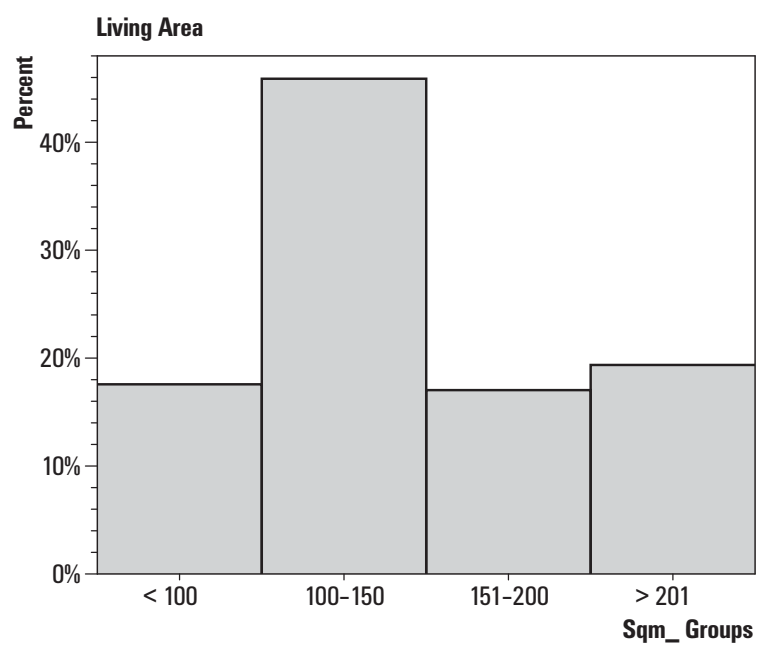

Figure 3. Living area of the houses

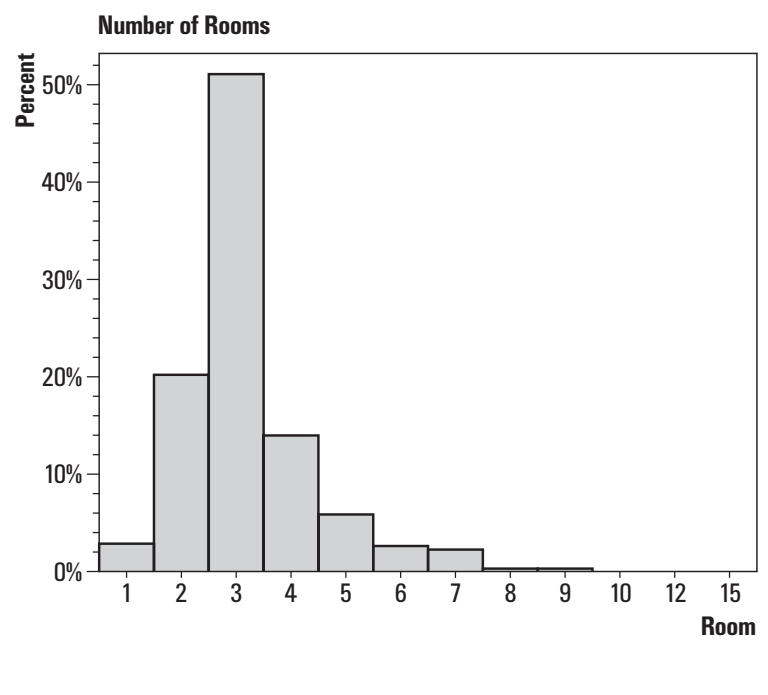

Figure 4. Number of rooms in the housing units 


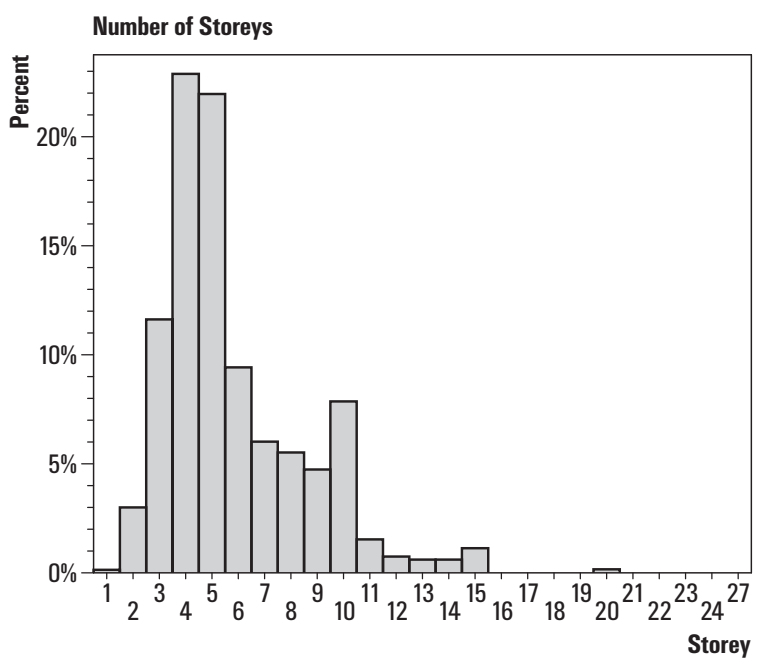

Figure 5. Number of storeys of the buildings

In most of the housing studies, neighbourhoods are defined as areas with homogeneous housing characteristics, property values, socio-economic property characteristics, political jurisdictions, and school districts (Clapp and Wang, 2006). Therefore, like the studies by Watkins (2001) for Glasgow, Goodman and Thibodeau (2003) for Dallas and Kauko (2004) for Amsterdam, administrative boundaries are taken on board as submarkets boundaries in this research. Housing submarkets are constructed using the administrative boundaries of the Istanbul Greater Municipality. This assumption also allows for the identification of the socio-economic structure, neighbourhood quality and housing prices segmentation in Istanbul.

In this research, each transaction is associated with its neighbourhood administrative boundary. The survey was not held in each of the neighbourhoods and therefore the adjacent neighbourhood to the submarket where the housing unit exists, is taken as the representative neighbourhood. In order to display the socio-economic and neighbourhood quality characteristics of the neighbourhoods, the dataset is composed from the survey held in 2005

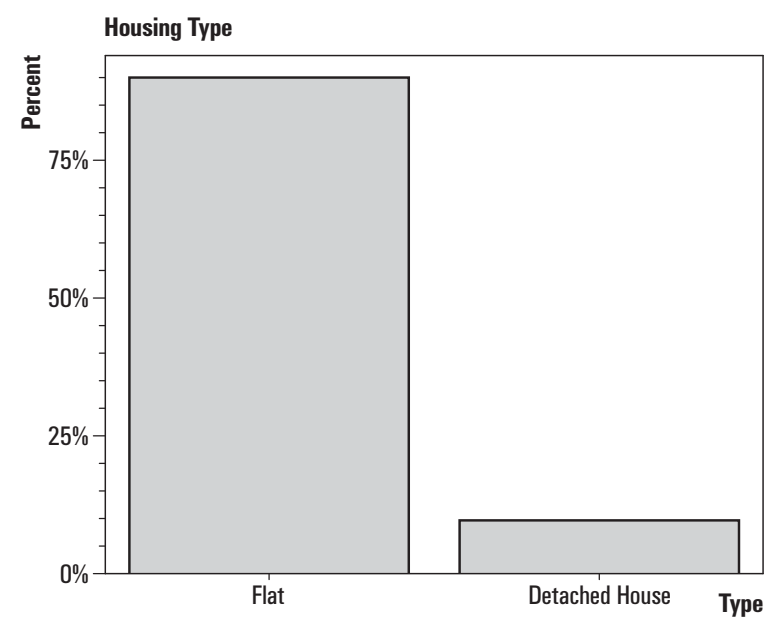

Figure 6. Housing type of the houses

by the Istanbul Greater Municipality. The data of this survey were collected according to a systematic sampling method with a sample size of 3,863 , and by taking the density and land values into consideration in some of the 946 neighbourhoods. This data set provides the socio-economic and neighbourhood quality characteristics of the hedonic model The variables for socio-economic characteristics such as income, travel time to jobs and schools, travel time for shopping, the length of time the inhabitants have lived in Istanbul, the length of time the inhabitants have lived in the neighbourhood, household size and the variables for neighbourhood quality characteristics such as satisfaction from schools, transportation, municipality, health service, cultural facilities, playground facilities, security, neighbours, home, neighbourhood quality are provided by this survey.

This is shown in Table 2, which presents the descriptive statistics for the neighbourhood characteristics provided from the survey of Istanbul Greater Municipality. The database comprises information for a range of key variables and these can be seen in Table 2 . 
Table 2. Descriptive statistics of socio-economic and neighbourhood quality characteristics of neighbourhoods N: 2175

\begin{tabular}{lllll}
\hline & Minimum & Maximum & Mean & Std. Deviation \\
\hline Average income & 333 & 4444 & 1072 & 811 \\
School satisfaction & 1 & 7 & 4.358 & 1.29282 \\
Transportion satisfaction & 1 & 7 & 4.781 & 1.112 \\
Municipality satisfaction & 1 & 7 & 4.61 & 1.2674 \\
Health service satisfaction & 1 & 7 & 4.103 & 1.3754 \\
Cultural facilities satisfaction & 1 & 7 & 3.735 & 1.4903 \\
Playground facilities satisfaction & 1 & 7 & 3.787 & 1.4182 \\
Security satisfaction & 1 & 7 & 3.382 & 1.4129 \\
Neighbour satisfaction & 1 & 7 & 5.792 & 0.7949 \\
Home satisfaction & 1.3 & 7 & 5.948 & 0.8361 \\
Neighbourhood quality satisfaction & 1 & 7 & 5.03 & 1.2122 \\
Travel time to jobs and schools & 5 & 95 & 28.66939 & 15.19925 \\
Travel time for shopping & 2 & 72.5 & 17.316 & 11.7994 \\
The length of time the inhabitants & 3 & 73 & 29.5135 & 9.483304 \\
have lived in Istanbul (year) & & & & \\
The length of time the inhabitants & 1 & 46 & & \\
have lived in the neighbourhood & & 6.5 & 3.487 & 0.6739 \\
Household size & 1 & & & \\
\hline
\end{tabular}

The average household income is $\$ 1,072$, ranging from $\$ 333$ to a maximum of $\$ 4444$. The average household size is 3.5 and ranges from 1 to 6.5 . The length of time the inhabitants have lived in Istanbul is 29.5 years whereas the length of time the inhabitants have lived in the neighbourhood is 13.5 years. Travel time for shopping is 17 minutes on average, whereas for jobs and schools it increases to approximately half an hour. In order to measure the satisfaction from different kinds of facilities, the respondents were asked to score these facilities on a scale from 1 to 7 , with 1 being unsatisfactory, and 7 being satisfactory. According to the results, the less satisfaction rates belong to security, playground and cultural facilities. On the other hand, health service, school, transportation, and municipality satisfaction rates are valued as average. The higher satisfaction scores belong to neighbourhood quality, neighbour quality and home satisfaction. The factors affecting the housing prices are measured according to the variables listed in Table 3.

\subsection{Methodology}

Housing prices can be modelled using hedonic price functions. The hedonic approach is based on the assumption that a residential unit is composed of a bundle of individual components, where each one has an implicit price. The theory of hedonic price is formulated as a problem in which the entire set of implicit prices guides both consumer and producer locational decisions in characteristics space (Rosen, 1974). The hedonic price model is a method by which the price of the housing unit is delineated by structural, locational, and environmental attributes. This technique is based on a statistical analysis that characterises the price of housing unit as a dependent variable, and the structural, locational, and environmental factors are employed as independent variables in order to explain the dependent variable that is housing prices. Housing prices are affected not only by the structural characteristics of the housing units, but also by the socio-economic, behavioural environment, 
Table 3. Variables and description of variables

\begin{tabular}{|c|c|}
\hline Variable used & Description of variable \\
\hline Price & The price of the housing unit in $\$$ \\
\hline Age & The age of the building \\
\hline Living area & The floor area of the housing unit \\
\hline Room & Number of rooms in the housing unit \\
\hline Total storey & The total storey of the building \\
\hline Low-storey & If the storey on which housing unit is situated is lower than 5 \\
\hline Flat & If the housing unit is a flat? Yes or no \\
\hline Detached & If the housing unit is a detached building? Yes or no \\
\hline Elevator & Does the building have an elevator? Yes or no \\
\hline Balcony & Does the building have a balcony? Yes or no \\
\hline Garden & Does the building have garden? Yes/No \\
\hline Site & $\begin{array}{l}\text { If the building is in a site with swimming pool, } \\
\text { garage and security unit }\end{array}$ \\
\hline School satisfaction & The satisfaction score for schools (1 very poor to 7 excellent) \\
\hline Health service satisfaction & The satisfaction score for health services ( 1 very poor to 7 excellent) \\
\hline Cultural facilities satisfaction & $\begin{array}{l}\text { The satisfaction score for cultural facilities } \\
\text { (1 very poor to } 7 \text { excellent) }\end{array}$ \\
\hline Playground facilities satisfaction & $\begin{array}{l}\text { The satisfaction score for playground facilities } \\
\text { (1 very poor to } 7 \text { excellent) }\end{array}$ \\
\hline Neighbour satisfaction & The satisfaction score for neighbours (1 very poor to 7 excellent) \\
\hline Neighbourhood quality satisfaction & $\begin{array}{l}\text { The satisfaction score for neighbourhood quality } \\
\text { (1 very poor to } 7 \text { excellent) }\end{array}$ \\
\hline Average income & The average income of inhabitants in the neighbourhoods \\
\hline Household size & Household size \\
\hline Living period in Istanbul & The length of time the inhabitants have lived in Istanbul(year) \\
\hline Living period in the neighbourhood & The length of time the inhabitants have lived in Istanbul (year) \\
\hline Travel time to jobs and schools & Travel time to jobs and schools \\
\hline Travel time for shopping & Travel time to shopping centres/areas \\
\hline Earthquake risk & The $\%$ of the buildings that will be highly damaged \\
\hline Continent & Europe: 1 , Asian: 0 \\
\hline
\end{tabular}

neighbourhood quality, and locational factors like amenities and disamenities. It is possible to interpret the implicit price of each attribute from the coefficients estimated from the hedonic function. This also allows comparisons between the prices paid for different qualities of the commodity, by examining individual at- tribute prices and the aggregate prices paid for heterogeneous housing units.

The hedonic price model is based on an assumption that the market contains a heterogeneous housing stock and heterogeneous consumers. Heterogeneity causes variation in house prices within a location, providing hous- 
ing consumers with a range of housing unit options. In addition, housing consumers differ according to socio-economic and behavioural characteristics. Different households with different socio-economic composition have different tastes for housing structures that vary with respect to a range of components like size, number of rooms, and construction type. The heterogeneity of the housing stock and housing buyers denotes that the urban housing system is composed of submarkets, each of which will have a different market price for property attributes.

Hedonic price estimation is often used in housing submarket studies. The most significant implication of heterogeneity in housing market modelling studies is segmentation in the housing market. The urban housing market is most accurately represented as a collection of diverse yet interrelated submarkets (Rothenberg et al., 1991). In many studies, urban housing markets were investigated by taking submarkets as bases (Goodman and Thibodeau, 1998; Fletcher et al., 2000; Bourassa et al., 2007). In this study, housing price determinants are examined by employing a hedonic pricing model that incorporates neighbourhood administrative boundaries which can reflect the heterogeneous physical and socio-economical configuration. The variables included in the hedonic function can be grouped in four categories: property characteristics, socio-economic characteristics, neighbourhood quality characteristics, and locational factors.

Property characteristics include price, age, living area, number of rooms and total storeys of the building. Other property characteristics are represented with dummy variables, such as the type of the property (flat, detached), the existence of an elevator, balcony and/or garden. In addition, the characteristic such as "site" represents the dummy variable if the housing unit location is in a secured site with swimming pool and garage. The other charac- teristic "low storey" embodies if the storey of the building is lower than 5. "Site" and "low storey" variables were taken into account with respect to the preferences of the house buyers in Istanbul. After the 1999 Marmara Earthquake, house consumers preferred to live in the lower storey buildings at the highly secured low density sites that have swimming pools and facilities.

Socio-economic characteristics are composed of average income of the household, household size, the length of time the inhabitants have lived in Istanbul and the length of time the inhabitants have lived in Istanbul. In order to capture the neighbourhood quality characteristics, the satisfaction from schools, health services, cultural facilities, playground facilities, neighbour satisfaction, and neighbourhood quality are examined in this study. The neighbourhood quality characteristics (satisfaction levels) are measured on a 1 to 7 Likert scale, 1 being "appalling" response, and 7 being an "excellent" response. The locational factors gauge the urban structure based on the built and natural environment elements. The travel time to jobs, schools and shopping areas (or centres) are examined with the intention of measuring the transportation infrastructure. The earthquake risk percentage measurement has been taken into account and was derived from predictions by the JICA (Japanese Agency for International Cooperation) (IBB, 2007).

The dependent variable is based on the data collected from the real estate agencies, as explained in the data section. The following hedonic price function is employed to estimate the factors affecting housing prices:

$$
\mathrm{P}=\beta_{0}+\beta_{1} \mathrm{X}_{1}+\beta_{2} \mathrm{X}_{2}+\beta_{3} \mathrm{X}_{3}+\beta_{4} \mathrm{X}_{4}+\varepsilon
$$

where: $\mathrm{P}$ is the vector of logarithm of transaction prices; $\mathrm{X}_{1}$ is the vector of variables for property characteristics; $\mathrm{X}_{2}$ is the vector of variables for socio-economic characteristics; $\mathrm{X}_{3}$ is the vector of variables for neighbourhood 
quality characteristics, and $\mathrm{X}_{4}$ is the vector of variables for locational factors. $\beta i$ ( $i=1,2$, $3,4)$ is the vector of coefficients and $\varepsilon$ is the error term. A log-linear functional form was employed because of the econometric problem arising from the occurrence of heteroscedacity in regression. Because the data from 348 submarkets with different characteristics are combined in the analysis, the errors are heteroscedastic. In order to reduce the error variance, a log-linear functional form was selected to improve the efficiency of parameter estimation (Rephann, 1998).

\section{RESULTS FROM THE ISTANBUL HOUSING MARKET}

The results of the hedonic price model are presented in Table 4. The overall $\mathrm{R}^{2}$ is 0.609 which compares well with others reported in the literature (Malpezzi, 2003; Rothenberg et al., 1991).

A logarithmic functional form is employed in this study. Overall the model produces implicit prices that are reasonably consistent with a priori expectations of the likely signs and magnitude.

In terms of the property characteristics, living area in the housing unit has the largest impact on the housing price. A $1 \%$ increase in the living area of the housing unit will change the logarithm of the housing price by 0.0000645 . The second most important variable among the property characteristics is site. This variable has been crucial since the 1999 Marmara Earthquake. High income level households have moved towards peripheral areas that have less earthquake damage risk with a solid ground formation and this tendency formed a phenomenon of gated communities with their own security, social and recreational facilities. The movements of high income group have been followed by the middle income group. Filtering has been assumed as shifts of households across dwelling qualities and changes in dwelling qualities (Rothenberg et. al., 1991). The middle income household group has preferred to live in the sites similar to the gated communities where there is a perceived high standard life quality.

The tendency to live in gated communities, or in sites, is not only because of the high life quality, existence of social and recreational facilities, but also because of the earthquake risk. The regulation system for construction of new buildings did not involve the high load bearing capacity construction rules before the 1999 Marmara Earthquake. This new regulation system and changing preferences of home purchasers mean that the supply side began to construct structurally higher load-bearing capacity buildings, and on more solid ground formations. A $1 \%$ increase in the earthquake risk percentage in a neighbourhood will have a significant impact on house prices. Since the Marmara Earthquake in 1999, inhabitants also prefer to live in low storey buildings as it is perceived that they will cause less damage. As a result most of the gated communities have detached houses.

In comparison to most studies on housing prices, age has an unusual sign. A 1\% increase in the age of the housing unit will lower housing price. Similar results for Istanbul were found by Ozus et. al. (2007), and Onder et. al (2004). It is argued that as the average age of housing units in a neighbourhood increases, it is expected that there will be more social and recreational facilities, and public investments such as schools. This result is also related with the variable "Living Period in Istanbul (the length of time the inhabitants have lived in the city)" in the socio-economic characteristics group because as the length of time the inhabitants have lived in Istanbul raise, the housing values also increase. Not only public facilities but also class concerns of the home buyer's causes such a result. The original inhabitants in Istanbul seek to avoid the ghetto areas where new migrants locate. As the income increases the housing values rise too. 
Table 4. The results of the model

\begin{tabular}{lll}
\hline Variables & Coefficients & $\mathrm{T}$ \\
\hline (Constant) & 1.693 & \\
Property characteristics & & \\
$\quad$ Living area & 1.150 & $38.259^{*}$ \\
Age & 0.055 & $5.185^{*}$ \\
Low storey & 0.025 & $2.194^{*}$ \\
Site & 0.086 & $5.378^{*}$ \\
Garden & -0.014 & $-1.093^{* *}$ \\
Socio-economic characteristics & & \\
Living period in Istanbul & 0.285 & $5.298^{*}$ \\
Average income & 0.174 & $5.940^{*}$ \\
House hold size & -0.070 & $-0.947^{* *}$ \\
Neighbourhood quality characteristics & & \\
Neighbour satisfaction & 0.180 & $2.215^{*}$ \\
School satisfaction & 0.115 & $1.932^{* *}$ \\
Health service satisfaction & -0.088 & $-1.801^{* *}$ \\
Locational characteristics & & \\
Travel time to job, schools & -0.001 & $-0.038^{* *}$ \\
Earthquake risk & -0.120 & $-6.251^{*}$ \\
Continent & 0.001 & $0.123^{* *}$ \\
Dependent variable: Housing price & & \\
R Square & 0.609 & \\
Adjusted R Square & 0.605 & \\
F & 156.122 & \\
Sample size & 1517 & \\
\hline
\end{tabular}

* denotes that coefficient estimates are significant at 1 per cent level and

** denotes a 10 per cent level of significance

Neighbourhood quality is also important and neighbour satisfaction is a significant variable. Previous studies have showed that that individuals prefer to live near others like themselves and decisions about whether or not to move and where to locate are influenced by a perception of the behaviour and characteristics of the current and potential neighbours (Ioannides, 2002). Interestingly, despite of the insights of access-space theory, the travel time to work does not affect values significantly. The reason for that unexpected result may be because of the polycentric structure of Istanbul. This finding is similar to others where there has been a rise in the spatial pull of several of the subcenters in the region of Los Angeles County (Richardson et. al., 1990) that has a polycentric urban pattern like Istanbul.

\section{CONCLUSIONS AND FURTHER RESEARCH}

This paper reports on the first stage of a larger research project. This research project seeks to build on the existing studies of the Istanbul market. Specifically the research aims to develop a model of house prices that captures neighbourhood-level price differences. The research employs a multi-level modelling framework as the main analytical tool. The re- 
sults of the multi-level model are examined in several ways. First, the results are compared to those generated by two different forms of the standard hedonic model. The first hedonic model estimates house prices within Istanbul, but largely ignores neighbourhood differences. The second model includes neighbourhood dummy variables as a proxy for submarkets within the model. This analysis compares the estimated coefficients, significance and explanatory power of the models. Secondly, the spatial pattern of the residuals will be explored. This analysis will use GIS techniques to systematically examine the weaknesses of the different modelling approaches. However, at present, much of this research is still at the development stage. The present paper reports the results of the basic hedonic model, which were then compared with other published studies of Istanbul.

In this research, it is aimed to find out the determinants of the housing prices in Istanbul. A market-wide hedonic price model is employed by taking into property characteristics, socio-economic characteristics, neighbourhood quality characteristics and locational characteristics. The dataset used for this hedonic model is composed of two dataset. The data of property characteristics is provided from two major real estate agent's websites and this data set contains 2,175 transactions of single-family homes sold in Istanbul in November 2006 and in April. The second dataset provides information about the socio-economic and the neighbourhood quality characteristics. This dataset is derived from a survey that was undertaken by Istanbul Greater Municipality. The data of the locational characteristics such as travel time to jobs, schools and shopping areas (or centres) are taken from the second data set. The earthquake risk percentage measurement which is one of the most important locational characteristics is taken into account from pre- dictions by the JICA (Japanese Agency for International Cooperation) (IBB, 2007).

The results of the hedonic model suggest that the housing price is determined by four types of characteristics: property, socio-economic, neighbourhood quality and locational characteristics. Among the property characteristics, living area being in a low storey building, being in a secured site (with swimming pool and garage), are found to have a positive impact on housing value. On the contrary to most studies on housing prices, age has a counterintuitive sign. Such similar results for Istanbul were found by Ozus et al. (2007) and Onder et al. (2004). Among the socio-economic characteristics, the length of time the inhabitants have lived in Istanbul, average income of the household and neighbour satisfaction, as a variable in the behaviour characteristics, have positive impacts on housing value. As expected, earthquake risk as a locational variable with a negative impact.

The results of this study also display the demand side preferences so that these can be used as a guide to improve the understanding within the supply side and investors. In addition to supply side and investors, policy makers and urban planners can use the results in order to analyze housing market behaviour.

For further studies, a second model will be employed, which includes neighbourhood dummy variables as a proxy for submarkets, and a multi-level modelling framework as the main analytical tool. The results of this can then be compared to those generated by two different forms of the standard hedonic model. The comparative analysis focuses on the estimated coefficients, significance and explanatory power of the models. Furthermore, the spatial pattern of the residuals will be explored and GIS techniques will be used to systematically examine the weaknesses of the different modelling approaches. 


\section{ACKNOWLEDGEMENTS}

I would like to thank two anonymous referees and Dr. Tom Kauko for their helpful, constructive comments. I am grateful to my $\mathrm{PhD}$ supervisor Dr. Craig Watkins who provided valuable suggestions that considerably improved this paper and the research. Any errors are naturally my own responsibility.

\section{REFERENCES}

Adair, A., Berry, J. and McGreal, W.S. (1996) Hedonic modelling, housing submarkets and residential valuation, Journal of Property Research, 13(1), pp. 67-83.

Basu, S. and Thibodeau, T.G. (1998) Analysis of spatial autocorrelation in house prices, Journal of Real Estate Finance and Economics, 17(1), pp. 61-85.

Bourassa, S.C, Hamelink, F., Hoesli, M. and MacGregor, B. (1999) Defining housing submarkets, Journal of Housing Economics, 8(2), pp. 160-183.

Bourassa, S.C., Cantoni, E. and Hoesli, M. (2007) Spatial dependence, housing submarkets, and house price prediction, Journal of Real Estate Finance and Economics, 35(2), pp. 143-160.

Clapp, J.M. and Wang, Y. (2006) Defining neighbourhood boundaries: Are census tracts obsolete? Journal of Urban Economics, 59(2), pp. 259-284.

Eurostat (2007) Statistical Office of the European Communities. [Online] Available at: http:// ec.europa.eu/eurostat/

Fletcher, M., Gallimore, P. and Mangan, J. (2000) The modelling of housing submarkets, Journal of Property Investment and Finance, 18(4), pp. 473-487.

Gallimore, P., Fletcher, M. and Carter, M. (1996) Modelling the influence of location on value, Journal of Property Valuation and Investment, 14(1), pp. 6-19.

Goodman, A.C. and Thibodeau, T.G. (1998) Housing market segmentation, Journal of Housing Economics, 7(2), pp. 121-143.

Goodman, A.C. and Thibodeau, T.G. (2003) Housing market segmentation and hedonic prediction accuracy, Journal of Housing Economics, 12(3), pp. 181-201.
Gokmen, G.P., Yuksel, D.Y., Erkok, F., Alkiser, Y. and Keskin, B. (2006) Evaluating and reducing earthquake risks of squatter settlements in Istanbul, Open House International, 31(1), pp. 116-124.

IBB (2007) İstanbul Büyükşehir Belediyesi [Istanbul Metropolitan Municipality]. [Online] Available at: www.ibb.gov.tr.

Ioannides, Y.M. (2002) Residential neighborhood effects, Regional Science and Urban Economics, 32(2), pp. 145-165.

Kauko, T. (2004) A comparative perspective on urban spatial housing market structure: Some more evidence of local sub-markets based on a neural networks classification of Amsterdam, Urban Studies, 41(13), pp. 2555-2579.

Keyder, C. (2005) Globalization and social exclusion in Istanbul, International Journal of Urban and Regional Research, 29(1), pp. 124-134.

Malpezzi, S. (2003) Hedonic Pricing Models: A Selective and Applied Review. In: O'Sullivan, A. and Gibb, K. (eds.) Housing Economics and Public Policy, Blackwells, Oxford.

Onder, Z., Dokmeci, V. and Keskin, B. (2004) The impact of public perception of earthquake risk on Istanbul's housing market, Journal of Real Estate Literature, 12(2), pp. 181-194.

Ozus, E., Dokmeci, V., Kiroglu, G. and Egdemir, G. (2007) Spatial analysis of residential prices in Istanbul, European Planning Studies, 15(5), pp. 707-721.

Rephann, T.J. (1998) Explaining property values: Quantitative evidence from Sweden, Paper presented at the 45th annual meeting of the North American Regional Science Association International in Santa Fe, New Mexico, USA on November 11-14, 1998.

Richardson, H.W., Gordon, P., Jun, M.J., Heikkila, E., Peiser, R. and Dale-Johnson, D. (1990) Residential property values, the CBD, and multiple nodes: further analysis, Environment and Planning A, 22(6), pp. 829- 833.

Rosen, S. (1974) Hedonic prices and implicit markets: Product differentiation in pure competition, Journal of Political Economy, 82(1), pp. 34-55.

Rothenberg, J., Galster, G., Butler, R. and Pitkin, J. (1991) The Maze of Urban Housing Markets, Chicago: University of Chicago Press. 
So, H.M., Tse, R.Y.C. and Ganesan, S. (1997) Estimating the influence of transport on house prices: evidence from Hong Kong, Journal of Property Valuation and Investment, 15(1), pp. 40-47.

Turkstat (2007) Turkish Statistical Institute. [Online] Available at: http://www.turkstat.gov.tr/ Start.do
Watkins, C. (1998) Are new entrants to the residential property market informationally disadvantaged? Journal of Property Research, 15(1), pp. 57-70.

Watkins, C. (2001) The definition and identification of housing submarkets, Environment and Planning A, 33(12), pp. 2235-2253.

\section{SANTRAUKA}

\section{STAMBULO BŪSTO RINKOS KAINŲ HEDONINĖ ANALIZE்}

\section{Berna KESKIN}

Šiame darbe siekiama išnagrinèti veiksnius, kurie daro įtaką būsto kainoms Stambule. Pasitelkus hedonini kainų modelị, tyrinejjami būsto kainas lemiantys veiksniai, atsižvelgiant ị nekilnojamojo turto charakteristikas, socialinius-ekonominius veiksnius, apylinkių kokybės bruožus ir vietos veiksnius. Rezultatai rodo, kad būsto kainoms itaka daro tokie veiksniai: gyvenamosios teritorijos dydis, pastato aukštingumas, buvimas sklype ir pastato amžius. Be šių veiksnių, būsto kainas Stambule veikia ir laikas gyventas mieste, vidutinès namų ūkio pajamos, patinkantys kaimynai bei žemės drebejimu rizika toje teritorijoje. Siūloma atlikti tolesnius tyrimus, suformuojant antra fiktyviuosius apylinkiu kintamuosius apimantị modelį, kuris bus taikomas kaip subrinkų pakaitalas, o naudojant daugialypę modeliavimo struktūrą bus siekiama išanalizuoti miesto būsto subrinkos sistemą. 